\title{
Különleges oktatási időszakok: felvételizők és szüleik tapasztalatai a digitális tanrendrö| ${ }^{1,2}$
}

\author{
Berényi Eszter \\ BERÉNYI EsZTER: ELTE, TáTK - berenyi.eszter@tatk.elte.hu
}

\begin{abstract}
ABSZTRAKT A tanulmány azt mutatja be, hogy hogyan érintette a digitális tanrend a hat-, illetve nyolcosztályos gimnáziumba felvételizőket. A Covid-19 alatti iskolabezárásokkal kapcsolatos releváns szakirodalmak és a kisgimnáziumi iskolaforma bemutatása után egy vegyes módszertannal készült kutatás eredményeinek segítségével kerül sor a két egymást követő időszak: a felvételizési felkészülés, majd az azt váratlanul követő iskolabezárás alatti időszak tapasztalatainak elemzésére. A két időszakban közös, hogy az iskola intézménye kevés szerepet vállal a tanulásban az érintettek számára, ezért a tanulók családjaira jóval több teher hárul, mint az egyéb időszakokban. A tanulmány bemutatja az érintett családok tanulástámogatási gyakorlatainak közös és eltérő elemeit a két időszakra vonatkozóan, és az ezekkel kapcsolatban felmerült föbb problémákat.
\end{abstract}

Kulcsszavak: középiskolai felvételi, Covid-19, iskolabezárás, család

Special times in education - what grammar school applicants and their parents have to say about the school closures during the Covid-19 pandemic

ABSTRACT The aim of this article is to scrutinize the experiences of applicants to the selective six-and eight-year long grammar schools during the Covid-lockdown of the schools. First the relevant literature on school closures during Covid-19 and the specialties of the early selective grammar schools will be presented. Then the application process, and the school lockdown period will be analyzed using the results of a mixed method research. The two periods have in common that the school as an institution plays a passive role in both periods for those involved. As a consequence the families must play a more active role in the educational activities of their children than in other, less special periods. The study presents the common and different features of the learning support practices of the affected families during the two periods and the main problems encountered by them.

Keywords: secondary school application, Covid-19, school closure, family

\section{BEVEZETÉS ÉS KONTEXTUS}

Magyarországon, hasonlóan számos más társadalomhoz, a 2020-as tavaszi időszakban a digitális oktatás hirtelen bevezetése és a jelenléti oktatás teljes szünetelése voltak a Covid-19 járványra adott legföbb oktatáspolitikai reakciók.

Ennek a tanulmánynak az a célja, hogy bemutassa, hogy hogyan érintette a digitális tanrend a hat-, illetve nyolcosztályos gimnáziumba felvételizőket. Két okból tünik érdekesnek

\footnotetext{
1 A tanulmány alapjául szolgáló kutatást az NKFIH- PD 123954 számú kiválósági projektje és az MTA bo_352_19 számú Bolyai-ösztöndíja támogatta.

${ }^{2}$ Köszönöm az anonim lektorok konstruktív kritikáit, amelyek nagyban segítették a kézirat véglegesítését.
} 
ennek a csoportnak a vizsgálata a digitális oktatás alatt. Az egyik, hogy miközben egyre többet tudunk arról, hogy milyen hatással volt a digitális tanrend a hátrányos helyzetű tanulókra, aközben eddig kevés szó esett Magyarországon arról, hogy megjelentek-e, és ha igen, milyen típusú problémák az előnyösebb társadalmi hátterü tanulók körében. Márpedig a hat- és a nyolcosztályos gimnáziumba felvételizők mindenképpen ilyen előnyös hátterű csoportnak tekintendők. Másrészt, hasonlóképpen a digitális tanrendhez, a felvételizők számára a felvételire való készülés bő féléves időszaka, amely éppen csak megelőzte a digitális tanrendet, szintén sok szempontból eltér az átlagos oktatási időszakoktól.

A tanulmány arra keresi a választ, hogy miben hasonlít, miben tér el a felvételizők tapasztalata a két időszakban: a felvételizési folyamat és a Covid-járvány alatti digitális oktatás idejében; melyik milyen típusú problémákat vetett fel a számukra, s arra is, hogy milyen nyomokat hagyott bennük a digitális tanrend. Cél továbbá a családok tanulástámogatási szerepének, illetve a szülők és a tanulók eltérő tapasztalatainak bemutatása is ezekről a „különleges oktatási időszakokról”. Mindezek bemutatása arra a kérdésre is választ adhat, hogy melyek az iskola azon társadalmi funkciói, amelyeknek a betöltését leginkább hiányolták a távolléti oktatás alatt a családok.

\section{A COVID-19 ÉS A „NYÁRI SZÜNET HATÁS”}

A Covid-időszak alatti iskolabezárások hatását több szerző (pl. Kuhfeld - Tarasawa 2020) az oktatáskutatásban már ismert „nyári szünet hatáshoz” méri, amely szerint is a nyári szünet során általában csökken a tanulók tudása. Ennek oka a kontaktórák és a tanulásra fordított idő csökkenése, a nyári szünet alatt ezek ideiglenes megszűnése. Ráadásul úgy tünik, hogy ez a tudásvesztés nem egyenlő arányban megy végbe mindenkinél, hanem a társadalmilag hátrányosabb helyzetüek tudása jobban csökken. A Covid-19 oktatási hatásaival foglalkozó első kutatások meg is erősítették ezt a párhuzamot a „nyári szünet hatással” (pl. Van Lancker Parolin 2020).

A Covid-19 járvány oktatási hatásai és a „nyári szünet hatás” között párhuzamot vonók elsősorban a tantermi oktatás hiányából fakadó problémákra mutatnak rá. Az egyenlőtlenségek pedig voltaképpen azért növekednek, mert minél kevésbé elérhető az iskola, annál nagyobb szerepet kell játszania a családnak abban, hogy ezt a hiányt kompenzálja, tehát a diákok teljesítménye nagyobb mértékben lesz családi hátterük függvénye, mintha tantermi oktatásban vennének részt.

Az iskola hiánya minden korábbi, tantermi oktatást nélkülöző, „különleges időszakra” (a nyári szüneteken kívül az időjárási okok, vagy tanársztrájkok, illetve korábbi járványok alatti iskolazárások) vonatkozó tudásunk szerint is jelentősen megnöveli a szülők mint tanárhelyettesítők szerepét a tudásátadásban (Bonal - González 2020: 640). Spanyolországban a 2020-as tavaszi iskolabezárások hatását vizsgálva a szerzők arra jutottak, hogy míg a kisgyerekes családokban az otthonlévő gyerekek a családi háttértől függetlenül kaptak sok szülői segítséget, addig az alsóközépfokon tanuló diákok esetében már szélesre nyílt az olló a sokat segítő felsőfokú és a jóval kevesebbet segítő alacsonyabb végzetségü szülök között (Bonal - González 2020: 648). Ugyanakkor az is látszik, hogy az oktatási intézményrendszer tervezett és rendszeres szolgáltatásaival (gyakori ellenőrzés, támogatás, kapcsolattartás) még a Covid-időszak 
alatt is képes javítani ezen az egyenlőtlen helyzeten (pl. Bayrakdar - Sait - Guveli - Ayse 2020). Minél kevésbé hagyják magukra tehát a családokat az iskolák, annál kevésbé „jósolható meg” a családi háttér alapján a tanuló teljesítményromlása egy ilyen tantermi oktatás nélküli időszakban.

A Covid-19 járvány miatti iskolabezárások alatt, egyéb iskolabezárásokkal ellentétben, nemcsak a gyerekek, hanem egész családjuk is „beszorult otthonaikba”: a szülők jelentős része azt az időt, amit korábban munkahelyükön töltött (akár azért, mert munkanélkülivé váltak, akár mert home office-ban dolgoztak), az otthonukban töltötte. A legtöbb iskoláskorú gyermeket nevelö társadalmi csoporttal kapcsolatban elmondható, hogy az otthonaik „multifunkcionális terekké váltak” s megszűntek a „biztonság és nyugalom” szigeteként müködni (Kenway - Epstein 2021: 12). A Covid nyomán átalakuló otthoni társadalmi tér által okozott változások visszaköszönnek Chen és munkatársai (2021) tanulmányában, akik egy USA-beli vizsgálat nyomán arról írnak, hogy miközben az alsóbb státuszú családokban az egzisztenciális szorongás erősebb, mint a felsőbb státuszú családokban, addig a közép- és felsőbb osztálybeliekre jóval jellemzőbb probléma, hogy bizonytalanok az otthoni napi rutinban és abban, hogy a lakásban strukturált körülményeket teremtsenek gyermekük tanulásának támogatására. A középső és a felsőbb rétegek jóval jelentősebb, a gyermekük otthoni tanulásával kapcsolatos stresszről számoltak be, mint az alsóbb státuszú családok (Chen et al. 2021: 17).

A Covid-19 miatti iskolabezárások tehát egyenlőtlenségnövelő szerepük mellett a különböző társadalmi státuszban lévő családok számára eltérő jellegű problémákat generálhatnak.

A 2020. tavaszi „digitális tanrend” időszaka Magyarországon sem egyformán hatott a diákokra: körülbelül 20\%-ukat nem tudták elérni a pedagógusok tapasztalatai szerint (Czifrus et al. 2020), de közöttük felülreprezentáltak azok a gyerekek, akik - vélhetően családi körülményeik, illetve eszközzel való ellátatlanságuk miatt - „tűntek el” a pedagógusok látóteréből 2020 tavaszán (Kende - Messing, 2020). Mindez összefügg azzal, hogy a digitális tanrendet egy olyan oktatási rendszer volt kénytelen alkalmazni, amelyre különösen jellemző a tanári digitális kompetenciák hiánya (Buda 2017). Ezek között a körülmények között „a sikeres tanítás és tanulás kulcsszereplője a szülő lett" (Procháczik 2020: 213).

A tanulmány a továbbiakban a szülői szerepekre, percepciókra és tapasztalatokra koncentrál, a Covid-időszakot egy másik, a hat- és nyolcosztályos gimnáziumi felvételi időszakkal összevetve.

\section{MIT ÉRDEMES TUDNI A HAT- ÉS NYOLCOSZTÁLYOS GIMNÁZIUMOKRÓL ÉS KIK FELVÉTELIZNEK ODA?}

A középiskolázás európai modellje eredendően jobbára elitista koncepciókból fakadt és a felsőbb státuszú családok gyermekeinek a felsőfokra való felkészítését célozta. Ennek fontos eszköze volt az iskolai szelekció, amely az előnytelenebb társadalmi hátterüek zömét sokáig kizárta a folyamatból. Ugyanakkor a 20. század második felére a középfokú oktatás a legtöbb oktatási rendszeren belül már az általános oktatás (general education) része, s expanziója azért is válhatott majdhogynem teljessé a fejlett társadalmakban, mert a társadalmi és gazdasági fejlődés sikerességének egyik kulcsaként tekintenek rá (Triventi - Kulic - Skopek - Blossfeld 2016). 
A 21. század elejére a középfokú oktatással kapcsolatos oktatáskutatói diskurzus heves vitákkal jellemezhető a korai szelekció és az éles tagozatosodás (tracking), illetve a komprehenzív iskolarendszer hívei között. A korai szelekció ellenzői hangsúlyozzák, hogy az iskola társadalmi meghatározottsága miatt a képességeket soha nem lehet teljesen függetlenül értelmezni a családi háttértől. Mindez egybecseng a tőkekonverziónak az iskolai egyenlőtlenségek újratermelődésében játszott szerepére vonatkozó elméletekkel (Bourdieu 1997).

A hat- és nyolcosztályos gimnáziumi felvételi a nemzetközi sztenderdek szerinti „alsóközépfokú" oktatást megelőzően vagy - a hatosztályos felvételi esetében - annak első szakaszában történik meg. Ilyen értelemben tehát a magyar oktatási rendszerre egyértelmüen jellemző a korai szelekció. Éppen a hat- és nyolcosztályos gimnazisták eredményeit vizsgálva mutatta ki Horn (2009), hogy minél koraibb az iskolai szelekció, annál erősebbek a fenti, újratermelődést elősegítő mechanizmusok. A tanulók zöme viszont 8 évig mégiscsak általános iskolába jár, ez a korai szelekció tehát nem vonatkozik mindenkire. Ezért tekinthetjük a magyar középiskolába rendeződést lépcsőzetes folyamatnak.

Nem sajátos magyar jelenség, hogy ahogy növekszik egy-egy oktatási szint expanziója, úgy veszít korábbi „elit” jellegéből, s ezzel párhuzamosan úgy jelennek meg olyan erőfeszítések, amelyek arra irányulnak, hogy jöjjön létre az adott oktatási szinten belül egy szelektív oktatási forma, amely fenntartja privilegizált jellegét. Ennek jellemző módja sok társadalomban a tandíjas iskolák felé való törekvés, az oktatásban végbemenő privatizáció (Verger et al. 2016: 16). Ez az elmúlt időszakban egyre erőteljesebben jelen van ugyan Magyarországon is, de a középosztály számára még mindig meghatározóbb jelenség a sokszor (bár nem mindig!) szintén állami fenntartású, zömében nem tandíjköteles, de nagyon szelektív hat- és nyolcosztályos gimnáziumok felé való orientálódás.

Az első két ilyen gimnázium 1989-ban indított képzést, majd a sikeren felbuzdulva, a következő tanévben 12, később egyre több iskola követte a „szerkezetváltó” trendet (Liskó - Fehérvári 1996: 6). Már néhány évvel az első ilyen gimnáziumok megjelenése után is egyértelmüen magasabb volt a szerkezetváltó gimnáziumokban tanulók szüleinek iskolai végzettsége még a hagyományos gimnáziumba járókénál is (Liskó - Fehérvári 1996: 98).

Ma Magyarországon az az Országos Kompetenciamérés 2018-as, 10-esekre vonatkozó adatai szerint miközben klasszikus, 4 osztályos gimnáziumba a tanulók 29\%-a járt, addig nyolcosztályosba 5, hatosztályosba pedig 9\%-nyian jártak. Az Országos Kompetenciamérés adatai azt is mutatják, hogy továbbra is igen előnyös társadalmi hátterü az ezekbe az iskolákba járó diákok összetétele. 


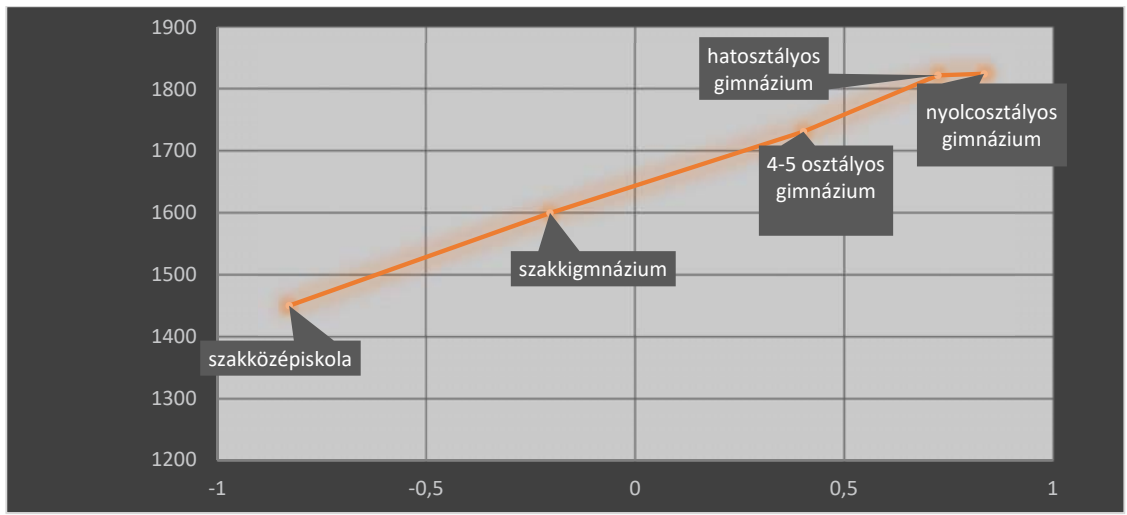

1. ábra Tizedikesek szövegértés eredményei (pontszámok; függőleges tengely) és családi háttér (standardizált skála; vízszintes tengely) összefüggései iskolatípusonként (OKM 2018)

Forrás: OKM 2018 adatbázis, saját számítás

A fenti ábrából az is látszik, hogy a kimagasló tesztpontszámok az iskolatípusonkénti családi átlagokkal együtt emelkednek, azaz a jó eredmények erőteljesen korrelálnak a bemeneti szelekcióval.

Mindennek persze a már az általános iskolás fokon is rendkívül szelektív magyar iskolarendszer „ágyaz meg”: míg a legelőnyösebb összetételü általános iskolákból az adott évfolyam akár 15-20\%-a (Berényi 2019) nyújtja be jelentkezését ilyen gimnáziumba, addig az általános iskolák zöméből szinte alig jelentkezik valaki - számukra a szerkezetváltó gimnáziumok világa mintha nem is létezne. A középfokba rendeződésnek ez a lépcsőzetessége, rendkívül erőteljes módon ágyaz meg tehát az önszelekciónak, azaz annak, hogy alsóbb státuszúak már eleve ne akarjanak olyan iskolákba jelentkezni, amelyek „köztudottan” a magasabb státuszúak iskolái.

A tanulmány a továbbiakban ennek a különleges csoportnak és szüleiknek a gyakorlatait és tapasztalatait elemzi.

\section{MÓDSZEREK}

A cikk alapja egy olyan vegyes módszertanú kutatás, amely a hat- és nyolcosztályos gimnáziumokba felvételizést tervezőkkel foglalkozik. A kutatás magát a felvételizési folyamatot vizsgálja, s a folyamat teljes megértése érdekében követéses módszertannal dolgozik.

A kutatás kvantitatív részére a 2019/20-as tanévben került sor. 2019 őszén 606 hat- vagy nyolcosztályos gimnáziumba felvételizni tervező gyerek szülője töltötte ki a kérdőívet, s közülük 2020 tavaszán, immár a felvételi eredmények birtokában, 292-en töltötték ki a másodikat is. A kérdőívet kiküldtük az átlagnál több kisgimnáziumi felvételizőt „produkáló” általános iskoláknak, illetve a hat- és nyolcosztályos gimnáziumoknak is, kérve őket, hogy terjesszék a velük kapcsolatban lévő szülők körében. Ezenkívül Facebook-hirdetésen, valamint médiamegjelenéseken keresztül (index.hu; noklapja.hu) is terjesztettük a kérdőív linkjét. A mintavétel nem volt, és nem is lehetett reprezentatív, hiszen nincs semmiféle adatunk arra nézve, hogy 
kik alkotják a vizsgált - kisgimnáziumi felvételit tervezők - populációját. Az Oktatási Hivatal adatai szerint a túljelentkezés 30-40\%-os ezekbe az iskolákba, amit ha összevetünk az 1. ábrán is látható, a végül is ezekbe az iskolákba be is jutók családi hátterével, arról tanúskodik, hogy már a jelentkezők csoportjában is felülreprezentáltnak kell lennie az előnyös társadalmi hátterűeknek. Bár a kutatás a jelentkezőknél nagyobb csoportot vizsgált - a jelentkezést fontolgatókét - a várakozásoknak megfelelően a kérdőívet kitöltők között magas arányban képviseltetik magukat az előnyös társadalmi hátterűek.

1. táblázat $A$ kérdőívet kitöltők néhány fontos alapadata és mintán belüli eloszlása

\begin{tabular}{|c|c|c|}
\hline & $\begin{array}{l}\text { Eredeti válaszadók, \% } \\
\qquad(\mathrm{N}=606)\end{array}$ & $\begin{array}{l}\text { Mindkét kérdöívet } \\
\text { kitöltők, \% }(\mathrm{N}=292)\end{array}$ \\
\hline 6-osok aránya & $57,8 \%$ & $62,3 \%$ \\
\hline 4-esek aránya & $42,2 \%$ & $37,7 \%$ \\
\hline $\begin{array}{l}\text { Szülök iskolai végzettsége: alacsony (egyik szülőnek } \\
\text { sincs felsőfokú végzettsége) }\end{array}$ & $9,5 \%$ & $7,9 \%$ \\
\hline $\begin{array}{l}\text { Szülök iskolai végzettsége: közepes (egyik szülőnek } \\
\text { van felsőfokú végzettsége) }\end{array}$ & $23,0 \%$ & $22,1 \%$ \\
\hline $\begin{array}{l}\text { Szülők iskolai végzettsége: magas (mindkét szülőjé- } \\
\text { nek van felsőfokú végzettsége) }\end{array}$ & $67,5 \%$ & $70,0 \%$ \\
\hline $\begin{array}{l}\text { Anyagi helyzet: legjobb (nem okozna problémát sem } \\
\text { egy hirtelen, egyszeri nagyobb, sem egy új, rendszeres } \\
\text { havi több tízezer forintnyi kiadás) }\end{array}$ & $51,0 \%$ & $55,1 \%$ \\
\hline $\begin{array}{l}\text { Anyagi helyzet: közepes (közepes, de megoldható } \\
\text { problémát okozna egy egyszeri vagy egy új, rendsze- } \\
\text { res, hirtelen pénzkiadás) }\end{array}$ & $31,1 \%$ & $30,1 \%$ \\
\hline $\begin{array}{l}\text { Anyagi helyzet: legkedvezőtlenebb (komoly } \\
\text { problémát okozna akár egy egyszeri, akár egy új, } \\
\text { rendszeres, hirtelen pénzkiadás) }\end{array}$ & $17,9 \%$ & $14,7 \%$ \\
\hline Budapest & $48,5 \%$ & $49,7 \%$ \\
\hline Megyeszékhely & $19,6 \%$ & $18,8 \%$ \\
\hline Egyéb város & $21,0 \%$ & $20,2 \%$ \\
\hline Falu & $10,6 \%$ & $11,0 \%$ \\
\hline
\end{tabular}

Forrás: Saját adatfelvétel

A kitöltők 48\%-a budapesti. Ez ugyan jóval több, mint a végül ténylegesen ilyen gimnáziumba bejutók esetében látható 30\%-nyi arány ${ }^{3}$, ugyanakkor a kérdőívet a felvételizni ősszel szándékozók töltötték ki, s azt is tudjuk, hogy a budapesti helyekre jóval nagyobb a túljelent-

\footnotetext{
${ }^{3}$ A 2018-as Országos Kompetenciamérés 8-os évfolyami adatbázisa alapján.
} 
kezés, mint az egyéb települések férőhelyeire. Ebből arra lehet következtetni, hogy a kérdőív mintájában felülreprezentáltak a budapestiek, de nem elsöprő mértékben.

\section{EREDMÉNYEK}

\section{A felvételire készülés mint különleges tanulási időszak}

Még soha senki nem vizsgálta az önszelekció konkrét állomásait a kisgimnáziumi felvételi folyamatban. A kutatás longitudinális jellegéből fakadóan most lehetőség nyílt erre.

A kérdőívet kitöltőkre kifejezetten előnyös és biztos családi háttér a jellemző (lásd 1. táblázat). A második kérdőív adataiból világossá válik, hogy még ezen az eleve előnyös összetételü csoporton belül is igaz, hogy az előnyösebb iskolai végzettségü szülök gyermekei jóval nagyobb arányban nyernek végül is felvételt, mint előnytelenebb hátterü társaik. Még érdekesebb az az adat, amely a menet közbeni önszelekcióról tanúskodik: nemcsak azt érdemes észrevenni, hogy a mindkét diplomás szülős családok esetében jóval nagyobb a folyamat végére a felvettek aránya, de árulkodó az az adat is, amely azokra vonatkozik, akik ugyan az első kérdőív felvételének időpontjában (2019. ősz) még tervezték a felvételizést, de aztán végül is mégsem adták be jelentkezésüket gimnáziumba: a nem diplomás szülők gyerekeinek több mint egynegyede ilyen, miközben a kétdiplomás szülők gyerekei közül csak kevesebb mint minden tizedik. Azaz, bár a minta sajátosságai miatt itt már csak nagyon alacsony esetszámok vannak, de az a következtetés mindenképpen levonható, hogy a felvételizés fontolgatásáig eljutó, nem diplomás szülők gyermekeinek az esetében kifejezetten jellemző a menetközbeni lemorzsolódás a felvételi folyamatban.

2. táblázat A szülők iskolai végzettsége és a sikeres felvételi $(N=292)$

\begin{tabular}{|l|c|c|c|}
\hline & Felvették & Nem vették fel & Nem is jelentkezett \\
\hline Egyik szülőnek sincs diplomája & $45,5 \%$ & $27,3 \%$ & $27,3 \%$ \\
\hline Egyik szülőnek van diplomája & $50,9 \%$ & $27,3 \%$ & $21,8 \%$ \\
\hline Mindkét szülőnek van diplomája & $71,6 \%$ & $18,6 \%$ & $9,8 \%$ \\
\hline
\end{tabular}

Forrás: Saját adatfelvétel

A digitális oktatással kapcsolatos egyik alapvető tapasztalat, mint már a fentiekben láttuk, hogy igen jelentős terheket ró a családokra. A kisgimnáziumi jelentkezők csoportja azért különösen érdekes ebből a szempontból, mert az ő esetükben a Covid-időszakot közvetlenül megelőző körülbelül félévnyi időszakra is éppen ugyanez jellemző. A felvételizési folyamat kifejezetten sok készülést követel meg a jelentkezni szándékozóktól, ugyanakkor az általános iskoláktól nem remélhetnek segítséget, mivel ezek rendszerint „kivonulnak” a folyamatból, sokszor igyekeznek szinte nem is tudomást venni a jelenségről, egyfajta nyílt titokként kezelik, s passzívak maradnak (Berényi 2019).

A kérdőívre adott válaszokból az derül ki, hogy a felvételizni szándékozóknak pusztán 11\%-a találkozott az iskolájában felvételi előkészítő szakkörrel, és pusztán 15\% (jelentős átfe- 
désben az előző csoporttal) számolt be arról, hogy iskolai tanóra keretében gyakoroltak a felvételire. De nemcsak a konkrét felkészítés hiányzik az általános iskolákból, hanem az informálódás lehetősége is: pusztán minden ötödik kérdőívkitöltő általános iskolájában kezdeményezett az iskola (legalább egyszer) olyan szülői fórumot, amelynek a kisgimnáziumi felvételi volt a témája.

A felvételire való felkészülés támogatása ezért igen nagy mértékű családi bevonódást kíván meg. A két időszak ugyanakkor teljesen eltérő abból a szempontból, hogy az egyik - a felvételizés - önként vállalt, a másik kényszerből és váratlanul következett be.

A „kisgimnáziumi” felvételizésre való felkészülés a többség számára hosszú hónapokon át tartó folyamatot jelent. A legtöbb felvételiző számára a felkészülés kezdőpontja általában szeptember (bár korábbi, tavaszi kezdés is gyakori).

A kérdőívet kitöltők gyermekeinek 94\%-a készül rendszeresen a felvételire. A készülés legjellemzőbb módjai az árnyékoktatáshoz kötődnek, mivel mint láttuk, alig van olyan, aki azt tapasztalta, hogy az általános iskolában, ahova gyermeke jár, létezne felvételire felkészítő foglalkozás.

A felkészülés során jellemzően vagy csoportos tanfolyamra, vagy magántanárhoz járnak a gyerekek, de sokan vannak, akik szüleikkel készülnek rendszeresen. A mintába bekerülök 65\%-a rendszeresen fizetett pénzt is a felkészülésért, ők hetente 5-6 ezer forintot áldoztak erre a célra.

A gyerekeknek mindez nem kevés idejükbe került: a hatodikos felvételizők például hetente több mint 200 percet töltöttek a felvételire készüléssel - ez négy és fél iskolai tanórának felel meg hetente. De a szülők is sok időt töltöttek felkészüléssel, átlagosan hetente egy óra negyven percben segítették a gyerekek felkészülését aktívan. A legtöbb családban rendszeresen előfordul, hogy a szülő ellenőrzi a gyakorlásként kitöltött teszteket, és javítja is azokat.

A szülőkre nemcsak az aktív tanulástámogatással töltött idő hárul, de az őszi félév során fejenként 2-3 nyílt napon is részt vesznek, aktív magjuk különböző szülői fórumokon kutat a fellelhető információk után.

A tavaszi második adatfelvétel idején visszatekintve, a szülők kétharmada arról nyilatkozott, hogy mind ők, mind a gyerekek több időt is szántak az írásbelire való készülésre a készülés utolsó, december-januári időszakában, mint korábban, az intenzitás tehát az írásbeli időpontjához közeledve fokozódott.

A kutatás tanulságai szerint a felkészülést tervezők 95\%-a meg is írja a központi írásbelit, és $87 \%$-uk be is nyújtja a jelentkezést legalább egy gimnáziumba.

Mindez azt jelenti, hogy a többség számára az aktív készülés egészen a szóbelikig tart, azaz február végéig-március elejéig.

Ez az időszak a felvételizők és családjaik számára egy rendkívül intenzív, a megszokottól eltérő időszak. A 2019/2020-as tanév különlegességét az adta, hogy éppen márciusban kezdödött a Covid-19 járvány miatti kényszerü digitális oktatási időszak, ami hasonlóan nagy terheket rótt az iskolás gyereket nevelő családokra, mint a hat- és nyolcosztályos felvételizés időszaka azokra, akik nekivágtak a felvételizésnek. 


\section{FELVÉTELIZÉS UTÁN. A DIGITÁLIS TANREND}

Mivel a 2. kérdőív kiküldése a 2020-as karanténidőszakra esett, ezért bár a kutatás eredeti célja nem a Coviddal foglalkozott, ebbe a kérdőívbe bekerült egy Covid-blokk, amely a felvételizők digitális tanrenddel kapcsolatos tapasztalatait tudakolta.

A felvételizőket a tavaszi Covid-helyzet nem rázta meg kifejezetten munkaerőpiaci helyzetükben. A második kérdőívet kitöltők közül 15\%-nyian voltak azok, akik bevételcsökkenésről számoltak be, de a túlnyomó többségre - a kitöltők háromnegyedére - ebben az időszakban az volt a jellemző, hogy teljes munkaidőben, de otthonról dolgozott.

2. ábra A Covid hatása tavasszal a munkavégzésre

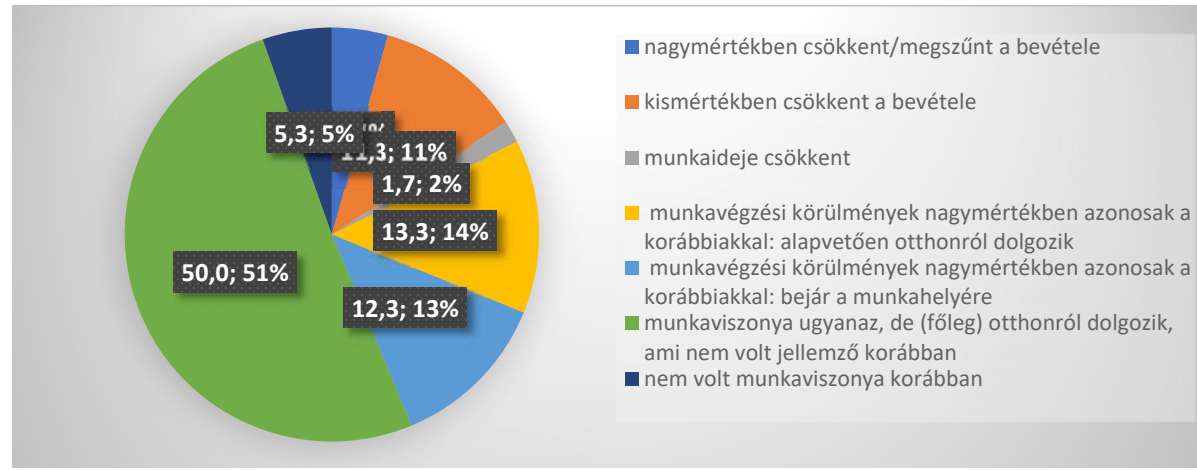

Forrás: Saját adatfelvétel

\section{TANULÁSTÁMOGATÁS}

A családok egy részében (a második kérdőívet kitöltők közül összesen 188 családnál) a felvételiző gyereken kívül van kisebb általános iskolás korú gyerek. Mivel feltételezhetően az ő digitális oktatási segítésük veszi el a legtöbb energiát a szülőktől, ezért még az alacsony elemszámok ellenére is, érdekes megfigyelni, hogy mennyi ideje ment el a szülőknek az ő támogatásukra, s mindez összevethető a felvételiző gyerekre szánt idővel és energiával.

Az, hogy a 2019/20-as tanév a felvételiző gyerekek családjában mennyire összetetten „különleges" időszak volt, kiugróan szembetűnő, ha a két időszakot (felvételizés időszakát és a digitális oktatás időszakát) összehasonlítjuk a felvételiző és a nem felvételiző gyerekek szempontjából. 
3. ábra Mennyi időt töltött a szülő a felvételi idejében tanulástámogatással két gyereke esetében? $(\mathrm{N}=188)$

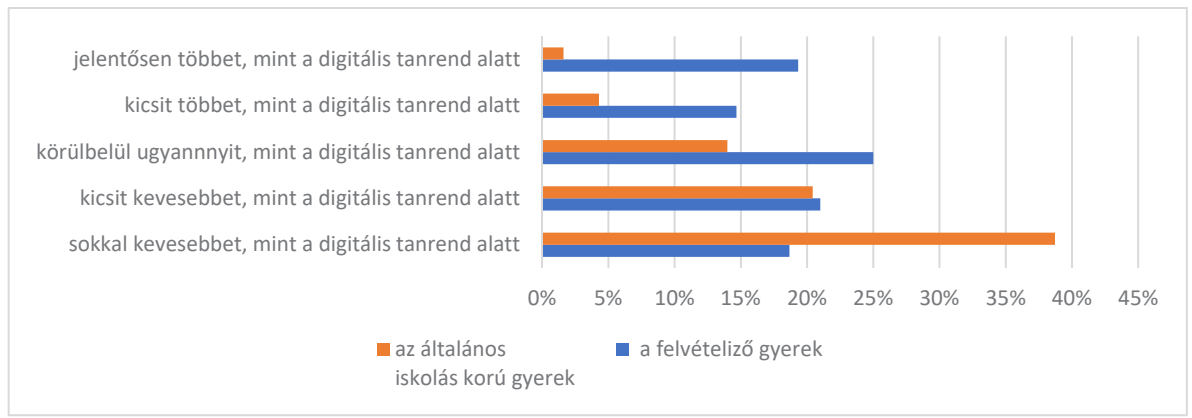

Forrás: Saját adatgyűjtés

Az látszik, hogy a nem-digitális, őszi időszakban a nem felvételiző gyerekek tanulásának támogatására a többség látványosan kevesebb időt szánt, mint később, a digitális oktatás alatt. Külön kiemelendő, hogy a kitöltők 38\%-a sokkal kevesebb időt töltött ilyesmivel. Adja magát az interpretáció, hogy ez - a nem digitális időszakban a nem felvételiző gyerekre fordított idő - tekinthető „normális”-nak, általában ez az a jellemző szint, amit a szülők tanulástámogatásra fordítanak. A legtöbb időszak ilyen: az iskola intézménye az irányított tudásátadás legtöbb terhét átveszi ezekben a „normál időszakokban” a szülőktől. Vannak azonban „különleges” időszakok, s mind a hat- és nyolcosztályos gimnáziumba való felvételizés, mind a digitális tanrend időszaka ilyen „különleges” időszakként fogható fel.

A felvételizés különleges időszak olyan értelemben, hogy eltér a megszokott általános iskolai rutintól, s olyan értelemben is az, hogy itt nem nyolcadik osztály utáni felvételizésről van szó, s az adott korcsoportnak csak töredékét (kb. 15\%) érinti. Fontos azonban, hogy az érintettek maguk választották ezt a „különleges” időszakot, míg a digitális oktatás úgy érintett mindenkit, hogy közben azt senki nem választotta, s nem volt rá felkészülési lehetőség sem.

A választottan különleges felvételizési időszakban a kérdőívet kitöltő szülők tanulástámogatásának eloszlása jóval kevésbé széles, mint az általános iskolás korú gyerekek tanulásának támogatása: a felvételizők esetében magas az aránya azoknak is, akik a felvételi időszakban, de azoknak is, akik a digitális tanrend időszakában szántak több időt a gyerek tanulásának támogatására.

Azaz sokan vannak, akiknek - ellentétben azzal, amire feltételezhetően számíthattak egy sikeres felvételizést követö, tét nélküli tavaszi oktatás során - a digitális oktatás során is kellett tanulástámogatásra időt fordítaniuk.

A szülői feladatok összetettségére rávilágít, ha megvizsgáljuk külön-külön a nyolc- és a hatosztályos felvételire készülőket. A felkészülés során a hatosztályos felvételi tétjét jellemzően nagyobbnak érzik a családok; ugyanakkor a negyedikes felvételizők még, életkoruknál fogva, egyértelműen abba a kategóriába esnek, akiket erősen kell segíteni a digitális oktatás során is (feltételezhetően ez nem pusztán életkori sajátosság, hanem arról is szó van, hogy az alsó tagozatosoknak rendszeresen jóval kevesebb valódi digitális kontaktóra „jutott”, mint a felsősöknek a 2020. tavaszi időszak során). S látszik is az adatokból, hogy a negyedikesek esetében 
mindössze 25\%-os az az arány, akik a felvételi időszakban többet segítették gyereküket, mint később, a digitális tanrend idején. A hatodikosoknál ez az arány már 39\%, azaz ennyien vannak azok, akik kicsit - de csak kicsit - „hátradőlhettek” a felvételit követően.

Ha azt nézzük meg, hogy konkrétan mennyi időt követelt a családtól a digitális tanrend alatti időszak, akkor azt látjuk, hogy mind a kérdőívet kitöltő anyák és apák, mind párjaik döntő többsége napi szinten foglalkozott kisebb, általános iskolás korú gyermekével a kitöltők (feltételezhetően legtöbbször: az anyák) átlagosan 60\%-a legalább napi 1-2 órát, de inkább többet. Az is kiderült a kérdőívre adott válaszokból, hogy más (nagyszülő, egyéb rokon) nem nagyon vett részt ebben a tanulássegítési folyamatban.

A következő ábrán az anyák és apák időráfordításának három értékét ábrázoltam a felvételiző és a kisebb gyerek esetében.

4. ábra Melyik szülő mennyi időt töltött tanulássegítéssel a 2020-as digitális oktatás időszakban?

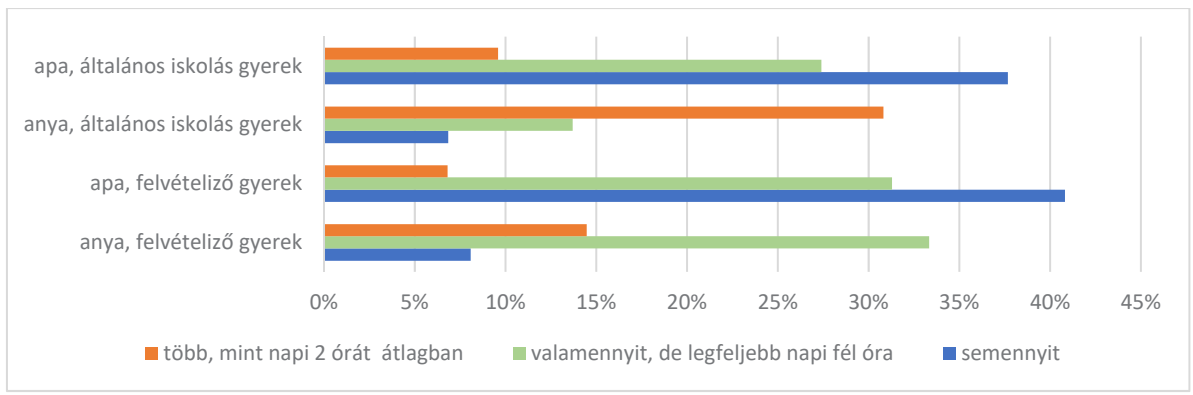

Forrás: Saját adatfelvétel

A felvételiző gyerekekkel jóval kevesebbet foglalkoztak a szülök a digitális tanrendi időszakban, mint az általános iskolás gyerekekkel. A különbség az anyák és az apák időbeosztása között ugyanakkor nagyon jelentős. Az apák relatív többségére nemcsak a felvételin túlesett, de kisebb általános iskolás gyermekük esetében is az a jellemző, hogy semennyi időt sem töltenek az ő tanulásuk támogatásával. Ez messze nem így van az anyákkal, egyik esetben sem. Az anyák esetében elenyésző azoknak az aránya, akik semennyi időt sem töltöttek tanulással, és nincs számottevő különbség a felvételit maga mögött tudó, és a kisebb általános iskolás gyerek között e tekintetben. Az anyák relatív többsége kifejezetten sok időt tölt az általános iskolás gyerek tanulásával - háromszor akkora arányban, mint az apák! De az is látszik, hogy ők a felvételin túlesett gyerekkel is foglalkoznak.

Ez nemcsak a háztartáson belüli egyenlőtlenségeket, de azt is jelzi, hogy a felvételiző gyermekek szülei, bár kevesebb időt szánnak felvételiző gyermekeikre a digitális tanrend alatt, mint kisebb gyermekeikre, de feltételezhetően azért többet, mint amennyit egyéb években a felvételi időszakot követő tét nélküli időszakban töltenének ezzel.

Érdemes kiemelni azoknak a felvételizőknek az esetét, akikről eddigre már tudni lehetett, hogy végigcsinálták ugyan a felvételi procedúrát, de végül nem vették fel őket gimnáziumba. Az ő tanulásuk támogatására a kérdőívet kitöltő szülők 46\%-a szánt a digitális tanrend alatt (is) napi egy-két óránál is több időt, feltételezhetően azért, mert a megszerzendő iskolai ered- 
ményeknek továbbra is nagy jelentősége volt, míg a már felvettek esetében a szülők kisebb tétjét érezték ekkor a tanulásnak.

\section{Hangulat}

A felvételizők szülei számára készített második (tavaszi) kérdőívben szerepeltek a hangulatukra és lelkiállapotukra vonatkozó kérdések, ezek segítségével a szülők és a gyerekek, illetve a két időszak hangulatait lehetséges összehasonlítani.

Úgy tünik, hogy a felvételire való készülés egyaránt megterhelő volt mind a gyerekeknek, mind a szülöknek - ez persze ismerve a rengeteg ráfordított időt és energiát, már nem meglepő. Kiemelendő, hogy - legalábbis a szülők beszámolói alapján - hasonlóan élték meg a szülők és a gyerekek a különböző lelkiállapotokat: a kérdőívet kitöltők leginkább izgatottabbaknak, várakozóbbnak, idegesebbnek és fáradtabbnak értékelték mind magukat, mind a felvételiző gyerekeiket ez alatt az időszak alatt. Ezekből visszaköszön a felvételi időszak intenzív feszültsége.

5. ábra A felvételizők és szüleik lelkiállapota és hangulata a felvételi időszak hajrájában ( $N=292)$

(átlagok, 1: nagyon nem jellemző; 5: nagyon jellemző)

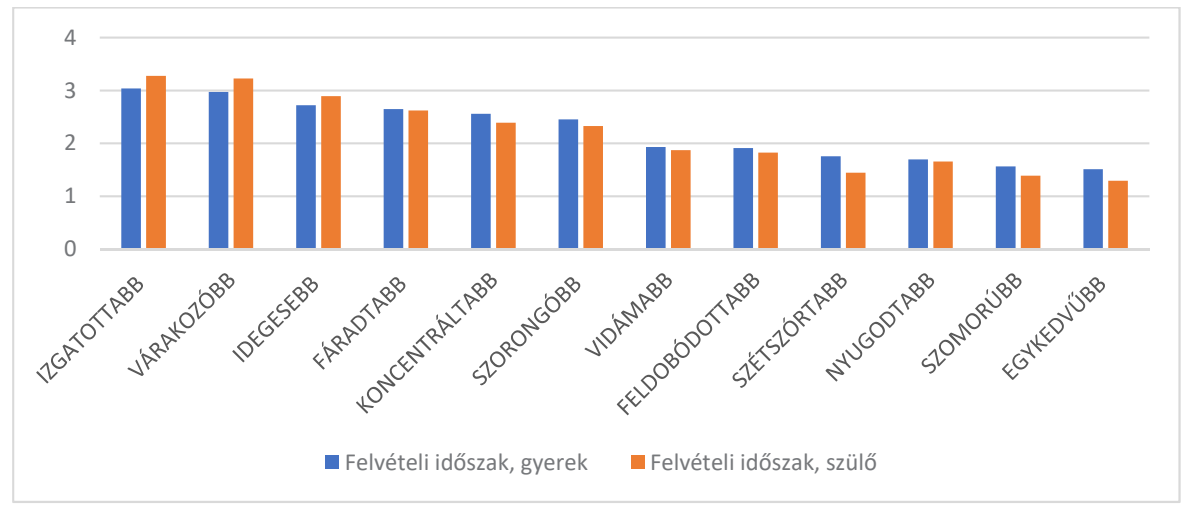

Forrás: Saját adatfelvétel

Az izgatottság, az idegesség, a feszültség és a fáradtság a gyerekek esetében függenek az életkortól: a hatodikosok esetében tapintható, hogy számukra nagyobb a tétje a felvételinek, és rájuk jellemzőbbnek tünnek ezek az állapotok. Sem a gyerekek, sem a szülők érzelmei nem függenek össze jelentős mértékben más - anyagi, iskolázottsági - háttértényezőkkel.

Mindezek alapvetően megváltoztak a digitális időszakra - de nagyon nem egyformán a két generáció számára. A felvételiző gyerekekről szemmel láthatóan lekerült a felvételi terhe, vidámak, nyugodtak és feldobódottabbak lettek, és a szorongás vált rájuk a legkevésbé jellemzővé.

Ellentétben azonban a felvételi időszakkal, ahol hasonló érzelmek és lelkiállapotok voltak jellemzőek a gyerekekre és a szülőkre, most úgy tünik, egészen más történt. A szülők mintha valamiféle fáradt apátiába zuhantak volna a felvételi időszak felfokozott izgalmából a digitális 
tanrend idejére. A legnagyobb változás esetükben az, hogy a felkészülés során leginkább jellemző izgatottság a legkevésbé jellemző érzetté válik; ugyanakkor a felkészülési izgalmak két másik jellemzője, az inkább negatív konnotációjú idegesség és fáradtság azonban, ami a gyerekeknél teljesen eltünik, a szülőknél nemhogy nem csökken, de egyértelmüen a legerősebb érzésekké válnak a digitális időszakra.

6. ábra A felvételizők és szüleik lelkiállapota és hangulata a digitális tanrend idején ( $N=292)$

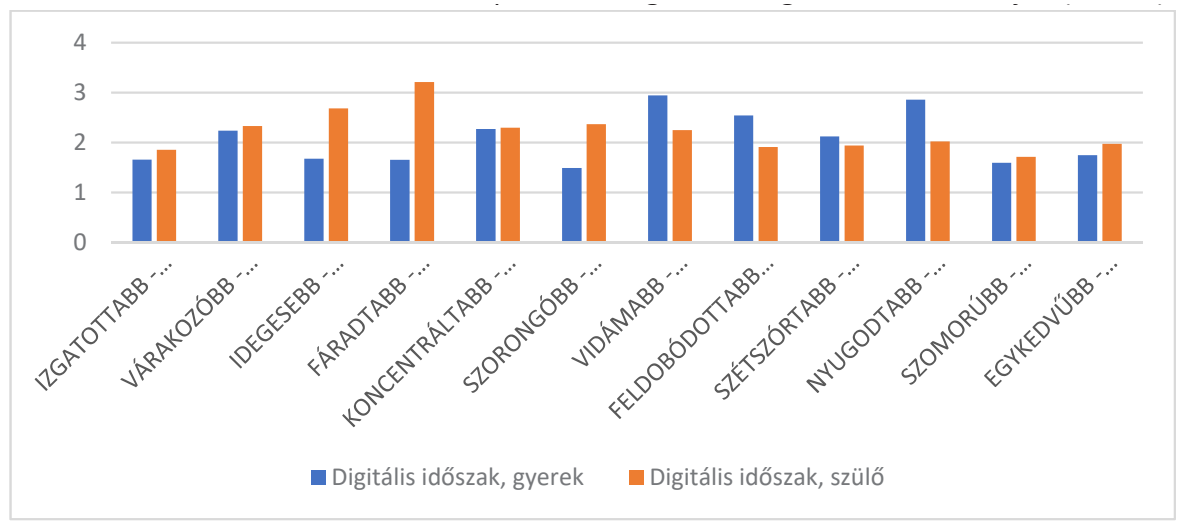

Forrás: Saját adatfelvétel

A szülők érzéseit egyértelműen befolyásolja, hogy van vagy nincs kisebb általános iskolás korú gyerek a családban. Jelentősen fáradtabbak, idegesebbek és szorongóbbak, viszont kevésbé vidámak és nyugodtak azok, akiknek van kisebb általános iskolás gyermeke, mint azok, akiknek nincs. Fontos azonban hangsúlyozni, hogy azoknak a szülőknek is kevésbé javult a hangulata tavaszra a felvételiző gyerekekhez képest, akiknek nincs kisebb gyereke.

Kiemelendő, hogy a szülők digitális időszak alatti érzelmeire másnak nem nagyon van hatása: sem annak, hogy a felvételiző gyereket felvették-e vagy sem, sem a munkaerőpiaci helyzetnek, s az iskolai végzettségnek és a lakóhelynek sem.

A felvételiző gyerekek digitális oktatás alatti érzelmei közül kiemelendő, hogy a kérdőív alapján a budapesti felvételizők a legnyugodtabbak és a falusiak a legkevésbé azok. Nem meglepő módon, akiket felvettek, azok kevésbé szorongóbbak és jóval várakozóbbak, mint azok, akiket nem vettek fel. A hatodikosok és a negyedikesek között nem látszik érdemi és szignifikáns különbség, kivéve azt, hogy a hatodikosok nyugodtabbnak tünnek, ami ismét csak a digitális oktatás eltérő tapasztalataira utal a két évfolyam között.

A tavaszi kutatás során a kérdőívben arra is kértük a kitöltőket, hogy válaszoljanak arra, hogy milyen problémákat érzékelnek a digitális oktatással kapcsolatban.

Potenciális problémákkal kapcsolatos állításokat sorolt fel a kérdőív, ezeket osztályozhatták a kitöltők, s egy skálán fejezhették ki azt, hogy mennyire értenek egyet az adott állítással.

Az alábbi táblázaton látszik, hogy általában melyik, zárt kérdés formájában megfogalmazott jelenség mennyire jelentett problémát a kitöltők számára: 
3. táblázat Milyen mértékben jelentenek problémát az alábbiak?

(1: egyáltalán nem; 5: nagymértékben)

\begin{tabular}{|l|c|}
\hline & Átlag \\
\hline Kevés online óra & 3,0 \\
\hline Rosszul kitalált távoktatás & 2,7 \\
\hline Mozgáshiány & 2,7 \\
\hline Szülőknek megterhelő a segítés & 2,6 \\
\hline Egészségügy miatti aggodalom & 2,2 \\
\hline Gyereknek megterhelő & 2,0 \\
\hline Anyagi aggodalom & 1,9 \\
\hline Összezártság & 1,8 \\
\hline Még nem iskolás gyerek & 1,5 \\
\hline Digitális eszközbeosztás & 1,4 \\
\hline Nincs megfelelő digitális eszköz & 1,2 \\
\hline
\end{tabular}

Forrás: Saját adatfelvétel

A vizsgált csoport nem élte meg nagyon problematikusan magát a digitális oktatást. Válaszaik leginkább középre húznak, ritkák az erősen problémát jelző válaszok. Relatív értelemben egyértelműen a legproblémásabb a kevés valódi online/kontaktóra jelensége, amelyet erősen közepes problémának éltek meg a válaszolók.

A többi problémát inkább közepesnek, vagy kifejezetten nem jellemzőnek élték meg, azonban ha ezek relatív sorrendjét nézzük, akkor rögtön a második „,helyezett” a valódi online órák mögött szintén egy oktatásszervezési kérdés: maga a rosszul kitaláltnak megélt távoktatás egésze. Ezekhez képest a skála másik végpontján két olyan állítás található, amelyek egyértelműen a családi anyagi helyzetének függvényei lehetnek, illetve lehetnének: ezek az eszközzel való ellátottság kérdései. Ezek nemcsak relatíve a legkevésbé problémás dolgok, de abszolút értelemben is jól látszik, hogy ebben a közegben a családok rendelkeznek elég eszközzel. 85\%-uk számára egész egyszerűen nem létezik a felvetett probléma. Ez a jelenség élesen kontrasztba helyezhető azzal, amit arról tudunk, hogy mi volt a helyzet a digitális oktatás ideje alatt a társadalom perifériáján élők iskoláiban.

Érdemes kiemelni, hogy a mintába bekerült alacsonyabb iskolázottságúak körében szignifikánsan magasabb azoknak az aránya, akik a digitális tanrend ideje alatt anyagi kérdésekben aggódni kezdtek. Ezt ők majdnem olyan nagymértékben értékelik problémának, mint azt, hogy gyermeküknek kevés az online órája.

A kérdezettek anyagi státusza kizárólag az anyagi jellegű problémák érzékelésével van nem meglepő irányú - összefüggésben.

Még egy dimenzió van, aminek érdemi hatása van a digitális oktatás alatti problémaészleletek valamelyikére. Márpedig az, hogy azokban a családokban, ahol van kisebb általános iskolás korú gyermek, a szülők számára a digitális oktatás megterhelőbbnek bizonyult. Kifejezetten többen vannak (32\%), akik számára mindez problémát jelent, míg ott, ahol nincs kisebb 
iskolás gyerek, csak 20\% az ilyen vélemények aránya. Nemcsak az abszolút értékben mért problémaérzet erősebb körükben, hanem a relatív is, hiszen a többiek által közepesen jelentős problémaként észlelt jelenség náluk felkúszott a dobogó második helyére a kevés online óra mögé.

Összességében elmondható a problémák észleléséröl, hogy legkevésbé az eszközhiány okoz problémákat, leginkább az oktatás jellegével elégedetlenek, s a felvételizők eleve privilegizált csoportján belül kevés változást okoznak a különböző háttérváltozók, ilyen értelemben viszonylag homogén csoportként írhatók le.

A szülőknek a kérdőív kitöltésekor lehetőségük volt szabadon kifejteni, ha volt valamilyen egyéb meglátásuk a digitális oktatás problémáival kapcsolatban. A kérdezettek több mint egyharmada írt ide szöveges választ, ami jól mutatja, hogy fontos és aktuális kérdésnek tartották mindezt. A továbbiakban ezen válaszok főbb dimenzióit mutatom be, amit a kutatás során szintén szülőkkel készített, tavasszal elkészült interjúk részleteivel is kiegészítek.

\section{Káosz kontakt nélkül}

A legerőteljesebben megjelenő észrevétel a digitális tanrenddel kapcsolatban a káoszra vonatkozik. Véleményeikben a szülők többször reflektálnak arra, hogy érzékelésük szerint az iskolák magukra hagyták a tanárokat, ugyanakkor úgy érzik, hogy a tanárok pedig magukra hagyták a családokat a digitális oktatással kapcsolatban. Mindez nagyon sokak szerint kaotikus viszonyokat okozott, föleg eleinte.

„Az egyik iskola összeszedetten, profin bonyolítja, a másiknál totális a fejetlenség...”

„A bevezetés káoszos volt az egyik gyerek sulijában, de mostanra kialakult a rend."

„Hetekig nehéz volt kideríteni, mi a feladat. Az iskola 6-7 különbözö felületen vagy platformon kommunikált."

„Maga az intézmény egyáltalán nem támogatja (és kéri számon) a tanárokat."

A zárt kérdésekből kirajzolódó legfőbb probléma, amely szerint is nem volt elegendő (vagy szinte egyáltalán nem volt) valódi kontaktóra, megjelenik a nyitott kérdésre adott válaszokban is - ez meg is erösíti, hogy ez a leginkább elsöprő erejü probléma, hiszen sok szülő annak ellenére fejtette ki ezzel kapcsolatban véleményét, hogy erre vonatkozó állítás szerepelt a kérdőívben, s volt alkalma ott jelölni ezt a problémát. A sommás véleményeket az alábbi néhány példa illusztrálja:

„Egyáltalán nincs kontaktóra, igazából minden tantárgyból csak feladatokat kapnak írásban, amiket el kell végezniük."

„Bizonyos tantárgyakból egyáltalán nincs órája a gyerekeknek, konkrétan semmit sem tanulnak adott tárgyakból, s nem világos, hogyan lehet így lezárni öket év végén."

„Az nem digitális oktatás, hogy naponta pdf-ben megkapjuk a tanulnivalót." 
„A helyi általános iskolában egyáltalán nincs digitális iskola. Csak egy-egy üzenet, hogy a tankönyvben mit tanuljon meg egyedül, illetve a munkafüzetben mit csináljon meg. Ez sem nem tanítás, sem nem érdekes, sem nem motiváló."

A vélemények jelentős része a tanárok informatikai/technológiai értelemben vett felkészületlenségét emeli ki. A felkészületlen és motiválatlan tanárokkal kapcsolatos élmények sok véleményben visszaköszönnek.

„Sok tanár nem is próbál jó feladatokat kitalálni, anyagokat megosztani, csak elküldi, mit olvassanak el, mit oldjanak meg a munkafüzetben. Sokan ráadásul az arányokat sem érzik, nem veszik figyelembe a tananyag mennyiséget, illetve hogy a szülöknek is dolgozniuk kell."

„A tanárok módszertanilag nem elég felkészültek az online oktatáshoz."

„A mi iskolánkban többet követelnek a tanárok, mint normál idöszakban. Az év közben összehozott lemaradást a szülökkel pótoltatják be."

„A tanmenet elörébb való mindennél, nem adtak a tanároknak időt felkészülni, nem segítették őket sok helyen, nem tanitották meg a gyerekeket az eszközök, appok, szoftverek használatára. Ahol a szülö se tudja, ott mi történt?"

„....utána én oktattam a Zoomra a tanárokat. Az iskola a felsősöknek elöirt vmi edmodot [?], nem ismerjük, de elég nehezen használható. Én elmondtam a szülöknek, hogy mi lesz a probléma, akkor mondták, hogy nem, aztán eltelt két hónap, és akkor mondták, hogy jaj, mégis... és akkor én erre rácuppantam, végigvezettem őket a Zoomon, hogy mit hogyan, én segítettem, voltak nehézségek, de egy hónap után végül mindenki megugrotta és lettek órák. Azóta beállt ez a rendszer, végre meghatározott menetrendje van." (interjúidézet)

\section{Munka és magánélet}

A kérdöív zárt kérdései között helyett kapott ugyan, de a nyitott kérdésre adott válaszok alapján a munka-magánélet összeegyeztetésének számos dimenziója merült fel, amelyeket szintén érdemes megemlíteni. Úgy tünik, mintha a családi otthon ez alatt az időszak alatt már-már totális intézménnyé válna a családtagok számára, amit nem könnyű elviselni.

„Az iskoláskorú gyermekekkel való tanulás miatt a munka éjszakára marad, emiatt néha kimerültek vagyunk."

„Pokoli volt az első 3 hét, miközben nekem is iszonyat mennyiségü munkám keletkezett, amit itthonról nekem is nehezebb volt megcsinálni. Mára már jobb."

„Összességében rengeteg, eleinte nettó 6-8 óra tanulás és segítése a gyereknek, kb. az első 5 hétben."

„Mivel mi szülök mindketten ugyanúgy dolgozunk, mint rendesen (sőt, többet), ezért megoldhatatlan számunkra, hogy a gyermekeink tanulásának szervezését és kisérését teljesen ránk háritja az iskola. Azokból a családokból indulnak ki, ahol az egyik szülö otthon maradt és ahol egyébként is 
szokás foglalkozni a gyerek tanulásával. Mi egyébként nem tanulunk otthon a gyerekkel, most pedig teljesen ránk van háritva ennek a felelössége."

„Igy, hogy mindenki itthon van, és boltba sem nagyon járunk, minden nap ki kell találni, hogy mit együnk, változatosan, abból ami itthon van/terem, és még meg is kell fözni."

„Most nagyon kevés a munkám, azt délelött lerendezem, és tudok foglalkozni a gyerekkel, és nem megoldhatatlan. Párhuzamos figyelmet igényel, hogy figyeljen... Folyamatos multitasking megy egész nap, de nem mindig igényel figyelmet... csak »figyelj, Petikém, mit csinálsz?«. Így, hogy itthon vagyok, sokkal nehezebb, és sokkal könnyebb..." (interjú)

A kérdőív zárt kérdései közül csak egy vonatkozik a gyerek lelkiállapotára, a nyitott kérdésre adott válaszok közül viszont nagyon sok vonatkozott a gyerekek szociális izolálódásának problémájára.

„a legmegterhelőbb a társaság, barátok hiánya a lányom számára, a bezártságot ilyen hosszú időre mi is nehezebben viseljük"

„A legnagyobb probléma, hogy a gyerek el van zárva az osztálytársaitól, barátaitól."

„Nagyon hiányoznak az osztálytársak, amelyet nem vált ki a mindennapos csetelés, online tér."

Végezetül álljon itt egy speciálisan a felvételizőkre jellemző, a gyerekeket szintén megterhelő probléma, ez pedig a váratlan búcsú, vagy inkább a búcsú lehetetlenségének érzete, hiszen a digitális tanrend kezdete egybeesett azzal az időszakkal, amikor a sikeres felvételizők kézhez kapták az örömhírt, hogy a következő tanévtől már másik iskolába fognak járni. Az elmaradt búcsú a digitális tanrend alatt hasonlóképpen érintette az érettségizőket, és a nyolcadik osztály után felvételizőket is, de a hat- és nyolcosztályos felvételik esete eleve terhelt azzal, hogy nem mindenkit érint, sokszor az általános iskolákban nem igazán nyíltan beszélnek a témáról, és sokáig bizonytalan, hogy végső soron elmegy vagy marad a tanuló az általános iskolában.

„Mivel felvették 8 osztályos gimnáziumba a lányom, ami március 16-án derült ki, és az iskolákat március 19-én zárták be a vírus miatt, egyik napról a másikra azzal szembesült, hogy nem találkozik többé a jelenlegi osztálytársaival, nem tud elbúcsúzni... ezt most nehéz feldolgozni, hogy egyik napról a másikra mindennek vége. És ez örök."

„Március 16-án jött ki a lista a Tompából', benne volt az osztálylétszámban. És ez ugye az a nap volt, amikor már nem volt suli, kezdődött az egész bizonytalan helyzet... és akkor ő meglátta ezt, és elsirta magát, hogy ő nem is akar elmenni innen, mert hiszen így nem is látja már többet az osztálytársait... Aznap tudatosult benne, hogy ő nem járhat többet iskolába..."

„Az iskolában lett volna már mód erre, de persze ennek most nem tudjuk a fórumát... Nem azért fél, hogy fél a retorziótól, hanem hogy nem tud rendesen elbúcsúzni, ezért vár ezzel a búcsúval..." (interjúrészlet)

${ }^{4}$ A gimnázium nevét az anonimizálás érdekében megváltoztattam. 


\section{KÖVETKEZTETÉSEK}

Mind a felvételi, mind a digitális tanrend időszakára jellemző az érintettek körében a szülők erőteljes bevonódása a tanulás támogatásába. A „nyári szünet” hatáshoz hasonló „különleges időszakokra” vonatkozó tapasztalatok azt mutatják, hogy minél kevésbé számíthatnak a családok az iskola intézményesített segítségére, annál inkább a családon „múlnak” a gyermekük tanulással kapcsolatos döntései és eredményessége. Ennek eltérő következményei vannak a különböző „különleges időszakokban”, hiszen azok sok fontos jellegzetességükben eltérnek egymástól: a digitális tanrend során 2020 tavaszán Magyarországon szinte egyáltalán nem müködtek az általános iskolák; a megelőző őszi felvételizési időszakban természetesen müködtek, ugyanakkor az érintettek számára az aktuálisan legfontosabb tanulási tevékenységben, a felvételire való felkészülésben nem nyújtottak segítséget. További jelentős különbség, hogy a digitális tanrend minden iskolást érintett, míg a felvételizésben való részvétel opcionális. Ezért aztán a hatások is másként csapódnak le a két esetben. A felvételivel kapcsolatos legfontosabb ilyen hatás, hogy az iskola passzivitásának következményeként eleve már csak a kedvezőbb státuszú tanulók és családjaik vágnak neki a nem kötelező hat- és nyolcosztályos felvételizésnek.

A digitális időszak alatt, amelyben mindenki érintett volt, az általam vizsgált csoportban egyáltalán nem volt probléma a digitális eszközökhöz való hozzáférés, miközben tudjuk, hogy hátrányosabb helyzetű rétegekben pedig ez okozhatta a legnagyobb problémát (pl. Hermann 2020). Általános tapasztalat volt ugyanakkor a tényleges kontaktórák hiánya, amelyet a vizsgált körben a nagymértékű szülői bevonódás kompenzált, ez azonban számos rossz érzést, nyomott hangulatot, kifáradást okozott a vizsgált családok körében.

A felvételizőknek még ebben az előnyös összetételü csoportjában is megjelennek olyan problémák, amelyekkel az oktatáspolitikának számot kellene vetnie, s amelyekre egy, a jövőben elöálló hasonló helyzettel kapcsolatban érdemes lenne felkészülni: a digitális oktatás módszertanának, a tanárok digitális hiányosságainak észlelése olyan problémák, amelyek valószínúleg általánosíthatók, még akkor is, ha a mintán belüli, relatíve előnytelenebb státuszúak problémaérzékelései arra is rávilágítanak, hogy az előnyösebb státuszúak valószínüleg egyszerüen jobban is megengedhetik maguknak, hogy ilyesmivel foglalkozzanak.

Az is kiemelendő, hogy milyen erősen megjelennek a munka és a magánélet összeegyeztethetetlenségének problémái ebben a helyzetben. Mindez a felvételizők családjainál nem egzisztenciális válságokat okoz, hanem erőteljes fáradtságot és feszültséget, mivel úgy érzik, erőn felül teljesítenek, amikor az iskola magukra hagyja őket és nekik kell tanárrá válniuk a digitális tanrend során. Mindez illeszkedik a rendelkezésünkre álló nemzetközi tudásba és arra hívja fel a figyelmet, hogy az idézett nemzetközi tapasztalatokhoz hasonlóan az elönyösebb társadalmi státuszúak számára is komoly problémák jelentkeztek a 2020-as digitális oktatás során.

A digitális tanrend időszaka a szülők problémaérzékelésein és lelkiállapotuk megismerésén keresztül azt is megmutatta, hogy mennyire téves az iskolát egyfunkciójú társadalmi intézményként felfogni, ahol elsősorban tudásátadás zajlik. A digitális tanrend „különleges” időszakában feltételezhetően éppen annak köszönhetően is növekednek az iskolai egyenlőtlenségek, hogy ezek a középosztálybeli családok, ellentétben a társadalom jóval hátrányosabb helyzetü családjaival, pont az iskola (átmenetileg) hiányzó tudásátadó funkcióját jól-rosszul, de kompenzálni képesek. A megelőző felvételizési időszakra vonatkozó egyik legfontosabb tapaszta- 
lat is éppen az, hogy nem is nagyon vágnak bele a folyamatba azok a családok, ahol a szülők ne vállalkoznának arra, hogy ebben az időszakban ők maguk is sok energiát és időt áldozzanak a felvételizéssel kapcsolatos tevékenységekre, s rendelkeznek azokkal a tudásokkal, amelyek képessé is teszik őket arra, hogy tanár-pótlékként segítsék gyerekeiket.

Ugyanakkor, mint ahogy a szülők válaszaiból kiderül, számukra is probléma, hogy a digitális tanrend alatt az iskola egy sor egyéb társadalmi funkcióját sem tudja betölteni, s ezeket már nehezebb megoldani: a munka és a magánélet, a magánéleten belül is a gyerekek tanulástámogatásának időbeli összeegyeztetése az iskola gyermekfelügyeleti funkciójának hiányát mutatja; s bár a középosztálybeli családokban nyilvánvalóan nem okoz gondot a gyerekek élelmezése (míg tudjuk, hogy hátrányosabb helyzetü közegben igen), az étkezésre és háztartásra szánt idő problémája is megjelenik az iskola kiesésével; s ugyanígy érzékelik az iskola hiányát abban is, hogy nem tud terepet biztosítani a gyerekek kortárs szocializációjának.

\section{IRODALOM}

Ball, S. - Vincent, C. (1998): 'I Heard It on the Grapevine': 'hot' knowledge and school choice. British Journal of Sociology of Education, 19(3): 377-400. https://doi.org/10.1080/ 0142569980190307

Bayrakdar, S. -Guveli, A. (2020): Inequalities in home learning and schools' provision of distance teaching during school closure of COVID-19 lockdown in the UK. Working Paper. ISER Working Paper series) http://repository.essex.ac.uk/27995/ (utolsó letöltés: 2021. 03.10.)

Berényi, E. (2019): A szegregációs jéghegy csúcsa, In: Fehérvári A. - Széll K. (szerk.): Új kutatások a neveléstudományokban. Budapest: L'Harmattan, 303-323.

Bonal, X. - González, S. (2020): 'The impact of lockdown on the learning gap: family and school divisions in times of crisis'. International Review of Education, 66(5-6): 635-655. https://doi.org/10.1007/s11159-020-09860-z

Bourdieu, P. (1997): Gazdasági tőke, társadalmi tőke, kulturális tőke. In: Angelusz R. (szerk.): A társadalmi rétegződés komponensei. Válogatott tanulmányok. Budapest: Új Mandátum, 156-177.

Buda A. (2017): Hatottak-e az IKT-eszközök a pedagógusok munkájára? Educatio 26(2): 216229. https://doi.org/10.1556/2063.26.2017.2.5

Czirfusz D. - Misley H. - Horváth L. (2020): A digitális munkarend tapasztalatai a magyar közoktatásban. Opus et Educatio, 7(3): 220-229. https://doi.org/10.3311/ope.394

Hermann Z. (2020): Hány diákhoz nem jut el az online távoktatás? Közgazdaság- és Regionális Tudományi Kutatóközpont, Közgazdaság-tudományi Intézet, https://kti.krtk.hu/ koronavirus/hany-diakhoz-nem-jut-el-az-online-tavoktatas/12769/ (utolsó letöltés: 2021. 04.20.)

Horn D. (2009): Age of selection counts: a cross-country analysis of educational institutions. Educational Research and Evaluation, 15(4): 343-366 https://doi.org/10.1080/ 13803610903087011 
Kende Á. - Messing V. (2020): Így tűnnek el a magyar közoktatásból a hátrányos helyzetű és roma gyerekek a járvány idején. https:/qubit.hu/2020/05/12/igy-tunnek-el-a-magyarkozoktatasbol-a-hatranyos-helyzetu-es-roma-gyerekek-a-jarvany-idejen (utolsó letöltés: 2021.04.20)

Kenway, J. - Epstein, D. (2021): The Covid-19 conjuncture: rearticulating the school/home/ work nexus. International Studies in Sociology of Education https://doi.org/10.1080/0962 0214.2021.1888145

Kuhfeld, M. - Tarasawa, B. (2020): The COVID-19 slide: What summer learning loss can tell us about the potential impact of school closures on student academic achievement. NWEA. Research Brief. Collaborative-Brief_Covid19-Slide-APR20.pdf (nwea.org) (utolsó letöltés: 2021.04.20)

Lannert J. (2018): Nem gyermeknek való vidék - A magyar oktatás és a 21. századi kihívások. In: Társadalmi Riport 2018, Budapest: Tárki, 265-285.

Proháczik Á. (2020): A tantermi és az on-line oktatás (tanítás és tanulás) összehasonlító elemzése. Opus et Educatio, 207-218. https://doi.org/10.3311/ope.390

Reay, D. - Ball, S. (1998): Making their minds up': family dynamics and school choice. British Educational Research Journal, 24(4): 431-448. https://doi.org/10.1080/0141192980240405

Triventi, M. - Kulic, N. - Skopek, J. - Blossfeld, H. P. (2016): Secondary school systems and inequality of educational opportunity in contemporary societies. In: Blossfeld, H. P. Buchholz, S. - Skopek, J. - Triventi, M. (eds.): Models of Secondary Education and Social Inequality: An International Comparison (Edulife Lifelong Learning series), Edward Elgar Pub, 3-24. https://doi.org/10.4337/9781785367267.00008

Van Lancker, W. - Parolin, Z. (2020): COVID-19, school closures, and child poverty: a social crisis in the making. The Lancet, 5: 243-244. https://doi.org/10.1016/S2468-2667(20) 30084-0

Verger, A. - Fontdevila, C. - Zancajo, A. (2016): The privatization of education. A political economy of global education reform. New York: Teachers College Press, 244. 